Author's acception version. For the final version of this chapter, please see The Journal of Colonialism and Colonial History 18.2 (Summer 2017), available via Project Muse at https://muse.jhu.edu/journal/29.

\title{
American Cows in Antarctica: Richard Byrd's Polar Dairy as Symbolic Settler Colonialism
}

In May 1935, the men of Richard E. Byrd's Second Antarctic Expedition arrived at Quantico, Virginia, aboard the S.S. Jacob Ruppert. They were returning from a stay of more than a year in the south polar regions at the base they called "Little America," dug into the Ross Ice Shelf. The men, however, did not represent the full complement of the expedition: accompanying them back from the far south was an exotic menagerie of animals. In addition to a large number of husky dogs familiar visitors to the south polar regions - the "floating zoo" included a galvanised iron swimming pool full of Antarctic penguins; a cage of "tropical love birds"; iguanas from the Galapagos; and two dairy cows along with a young bull. ${ }^{1}$ The Guernsey cows were returning home, having been stabled at Little America for over a year to provide milk for the expedition; the bull, born in high southern latitudes, was seeing the United States for the first time. These three animals went on to be feted throughout the nation: meeting the secretary of Agriculture; supping at a banquet table in the Commodore Hotel in New York; touring state fairs; featuring in newsreels and newspaper headlines; and starring in their own film. Three Guernseys were, for a short time, celebrity-explorers.

In Antarctic historiography, these Guernseys have been reduced to a whimsical episode, occasionally included in lists of polar "firsts" and mentioned as a quirky aside in accounts of the expedition. ${ }^{2}$ There are admittedly many ludicrous aspects to Byrd's attempt to "make dairy history" by taking cows to the frozen south. ${ }^{3}$ Our intention here, however, is to take this episode in polar history seriously, documenting the cows' experience and exploring the multiple meanings 
circulating around them. Such an approach, in foregrounding the experience of individual animals, reflects the ongoing impact of the "animal turn" in the humanities, ${ }^{4}$ but also produces unexpected insights into a comparatively unexamined aspect of polar history: the symbolic promotion of U.S. colonial interests in Antarctica.

While the history of introduced animals in the Antarctic is as old as human exploration of the continent and surprisingly diverse, Byrd's cows represent a unique case. Non-native animals transported to Antarctica can be divided into several overlapping categories, depending on the purpose which they were asked (or came) to serve: unintentionally introduced animals, such as rats and mice; working animals, such as dogs and ponies; animals destined to be consumed as meat, including dogs, ponies, pigs, sheep and cattle, ${ }^{5}$ and companion animals, most notably "Mrs Chippy," the carpenter's cat of Ernest Shackleton's Endurance expedition. Byrd's dairy cows are the most prominent (and possibly the only) example of a fifth category: animals brought to Antarctica to farm for their produce. Their ostensible purpose was to solve the expedition's socalled "milk problem" - the need (or so it seemed) for fresh milk to maintain the men's health. ${ }^{6}$ The Guernseys also represent a sixth category: animals taken to the far south for publicity purposes. As "the first cows ever to venture into the frozen wastes of the South Pole Region,"7 they not only functioned as a marketing gimmick for dairy farmers, feed suppliers and machinery manufacturers, they also added some novelty and newsworthiness to an expedition which, in contrast to Byrd's first Antarctic venture, threatened to be a little dull.

In the following, we provide a narrative of the cows' Antarctica experience, discussing the way in which their celebrity - inexorably attached to Byrd's own - was used to the mutual benefit of the expedition and its sponsors. We argue, however, that neither the Guernseys' solving of the "milk problem" nor their publicity value exhausts the human uses to which these animals were put. Contextualizing the episode within the cultural history of milk production, consumption and 
marketing in the United States in the early twentieth century, we suggest some further lenses through which Byrd's cows can be read. As workers, companions and publicity vehicles, these cows, we argue, were simultaneously a means through which Byrd enacted a form of symbolic settler colonialism on the Antarctic continent. ${ }^{8}$

\section{Colonialism in Antarctica}

The question of how to claim territory in a continent covered by slowly moving ice is one that that has plagued governments and expedition leaders since land-based exploration of Antarctica began, at the turn of the twentieth century. While in other potential colonies, ceremonies of national claim - proclamations, flag-raising - could be consolidated by long-term settlement, Antarctica resisted permanent human occupation. Even when expedition huts and scientific bases began to be established, the ice had a way of rejecting them - slowly covering them with snow and sometimes spitting them out at its edges. Operating in such a climatically hostile environment, nations with colonial aspirations in Antarctica had to rely heavily on symbolic rather than material occupation. Performative aspects of sovereignty claims thus loomed larger in the far south than in other, less icy, environments. The Third Reich's dropping of swastika-embossed darts over part of the Antarctic coast, for example, was only one of a number of similar exercises conducted by a range of nations. Polar geographer Klaus Dodds uses the term "sovereignty performance" to describe such national gestures, which include "maps, postage stamps, public education, flag waving, place naming, scientific activity, the regulation of fishing, flying pregnant women to the region and public ceremonies such as commemoration." 9

Despite its century-long history of such symbolic gestures of national ownership, Antarctica's lack of indigenous people, its resistance to permanent human occupation and the 1959 Antarctic Treaty's apparent rendering of the whole continent as "unowned" 10 have together resulted in a critical 
reluctance to understand its exploration and inhabitation through a colonial lens. Recently, however, this has begun to change, with Dodds identifying an "emerging engagement" with Antarctica by scholars who recognize that its unique history does not render it immune to "colonialism and associated practices such as mapping, surveying, and the subjugation of territory and non-human populations." 11 With Antarctica housing neither indigenous people nor settlers in the traditional sense, these critical efforts tend to focus on spatiality. Christy Collis, for example, examines both the early expedition hut and the contemporary scientific base as colonial spaces, ${ }^{12}$ and Adrian Howkins argues that "the Antarctic context, with its incredibly hostile environment, produced an ideal form of settler colonialism based purely on space." 13

The United States in the 1920s and 1930s represents a particularly interesting case in regards to Antarctic colonialism. By the time Byrd launched his first Antarctic expedition in the late 1920s, the U.S. had been absent from exploration of the region for nearly eighty years. After considerable activity in the early nineteenth century - numerous commercial sealing ventures as well as the United States Exploring Expedition (or "Wilkes Expedition") of 1838-42 - U.S. national aspirations in the polar regions became focussed on the far north. However, other nations - including Britain, Norway, France, Germany, Belgium, Sweden, Japan, Australia and New Zealand - had been active in the continent in the late nineteenth and early twentieth century - the so-called "Heroic Era" of Antarctic exploration. By the time Byrd was rebuilding Little America, several nations - Britain, France, New Zealand and Australia - had made sovereignty claims to wedge-shaped sectors of the continent. The United States' absence from "Heroic Era" exploration put it at a disadvantage in this regard. However, the U.S. had recently adopted the Hughes Doctrine, which stipulated that discovery alone was not the basis of a territorial claim, but had to be accompanied by effective occupation. This was something that the claimant nations, with a history of short-term expeditions, would struggle to show. Although a U.S. claim did not, in the end, eventuate, ${ }^{14}$ during the 1930 s the 
possibility was in the minds of both President Franklin D. Roosevelt and (particularly) Byrd himself. ${ }^{15}$

Within this context, Byrd's establishment of the series of bases he called Little America nominally miniature versions of the nation they represented - can be read as an obvious strategic attempt to settle, rather than merely explore, Antarctica. ${ }^{16}$ Broadly speaking, settler colonialism refers to the replacement of indigenous people by colonizers, who inhabit the colonial space with a view to permanency, rendering it familiar by recreating the surrounds of their homeland - through, for example, the planting of exogenous crops. While the nature of the Ross Ice Shelf meant that many of the stereotypical acts of settler colonialism were not available to Byrd, he nonetheless styled his expedition bases in the form of a frontier town, drawing on the settler colonial imaginary that he knew from his own nation's - and indeed his own family's - history. ${ }^{17}$ Scholars such as Elena Glasberg, David Day and Stephen Pyne have all examined the way in which Byrd constructed his expeditions as a form of frontier settlement. ${ }^{18}$ Pyne forcefully identifies the difference between Little America and the earlier expedition huts of the "Heroic Era":

Born into an old Virginia family with roots in seventeenth-century plantations, Byrd envisioned a society in Antarctica and cast himself in the role of the colonizer. He was the first man to really consider Antarctica as a site for quasi-permanent settlement, not simply as a terra incognita awaiting geographic discovery or an arena for individual exploits. His base at the Bay of Whales, Little America, was not simply an instrument for data collection - the usual 'hut' of Antarctic expeditions - but a village, a way of life, a society ..."19

Byrd was himself quite aware of the analogies between Little America and a frontier town, labelling photographs of the base included in Discovery "FRONTIER SETTLEMENT" and "MAIN 
STREET, LITTLE AMERICA."20 Byrd knew, of course, that there could be no real permanency to any of these efforts on a constantly moving iceshelf in an environment so hostile to human life. His gestures towards "settlement" were in the same vein as the "sovereignty performances" described by Dodds: symbolic acts made at least partly to strengthen a hoped-for future territorial claim.

While Pyne, like Collis and Howkins described above, tends to focus on the role of spatiality and the built environment in the Antarctic colonial enterprise, we want to draw attention to the use of animals - specifically cows. The role of non-human agents - and particularly livestock - in European colonization has long been recognized by postcolonial critics, and cows in particular played an important role in the early settlement of the United States. ${ }^{21}$ If Byrd was trying to establish a frontier village, then his inclusion of livestock in his expedition can be read as a symbolic gesture towards traditional settler colonialism. ${ }^{22}$ The image of the explorer hero, descendant of one of the First Families of Virginia, bringing cattle to a new land and successfully farming them there was a potent one at a time when his nation had adopted settlement as a criteria for sovereignty, and territorial claims on the Antarctic had been made by several other nations.

Byrd was not alone in recognizing the symbolic nationalist uses of animals in the polar regions. Peder Roberts and Dolly Jørgensen have examined the national significance of penguins transferred to Norway and reindeer to the subantarctic island of South Georgia in the first half of the twentieth century. As they note, however, South Georgia is not radically different, climatically, from the European Arctic. Continental Antarctica is a quite another scenario. No land mammal could be expected to survive, let alone thrive, unaided on the Ross Ice Shelf; Byrd's cows were certainly not intended as part of any kind of long-term acclimatization process and cannot be framed as ecological imperialism. However, just as the reindeer's "thriving presence”, according to Roberts and Jørgensen, "revealed something about the capacity for Norwegians to control polar environments," ${ }^{23}$ so the survival of Byrd's dairy cows said something about the U.S.'s ability to 
occupy the continent. Byrd must have known that a "dairy" on the Ross Ice Shelf was impractical and (as we show below) unnecessary - but, as planting crops was a non-option, farming animals was the next best item in the settler colonial repertoire that he was drawing on to symbolically establish U.S. long-term occupation of Antarctica. The function of cows as colonial agents in Antarctica, then, would only ever be symbolic, but this does not detract from its significance.

One challenge for Byrd - as for all Antarctic expedition leaders - was conveying the nature and significance of his expedition to his compatriots at home. With no one other than its own members to witness the expedition's achievement, media coverage was central to establishing its particular mode of occupation of Antarctica. As outlined below, Byrd was an old hand at generating popular interest in his adventures, and his sudden decision to take cows to Antarctica is evidence of this media-savvy. He would have known that a stunt like this would inevitably increase media attention to his endeavour, helping to generate funds to cover its expenses but also, more broadly, promoting American interests in Antarctica. The cows' publicity value was a vital part of their role as colonial agents.

\section{Selling the Second Byrd Expedition}

In 1932-33, when Byrd began to organize his second Antarctic expedition to conduct geographical and scientific research, fundraising was paramount. Although assisted by the state, the expedition was privately funded, through cash donations, loans, sponsorship and media deals. To achieve this backing, Byrd traded on his considerable celebrity. A career naval officer, he had made his name as an explorer and aviator in the mid-late 1920s with two polar "first": flights over both the north and south poles. ${ }^{24}$ In the early 1930 s, however, his efforts were hampered by the depression-era economic climate, as well as the perception that this enterprise lacked the excitement and novelty of his previous two polar journeys: “... there was no spectacular objective, no tour de force such as a 
polar flight, that would create great public interest." ${ }^{25}$ However, Byrd was adept at finding new sources of interest, including a plan to make the first regular radio bulletins from the far south. ${ }^{26}$ In the end, deals with Paramount, CBS Radio and General Foods (the latter sponsoring the radio coverage in return for advertising space) meant that this expedition was "the most media-saturated event in the history of the geographical exploration of Antarctica."27

The unusual decision to take dairy cows to Antarctica to provide milk was part of this concerted drive for novelty and publicity. Through negotiations with the American Guernsey Cattle Club (AGCC), three were selected, all from prominent farms in the Eastern states: Deerfoot Guernsey Maid, from Deerfoot Farms in Southboro, Massachusetts (Figure 1); Foremost Southern Girl from Emmadine Farm of Hopewell Junction, New York; and the pregnant Klondike Gay Nira, from Klondike Farm in Elkin, North Carolina. ${ }^{28}$ Deerfoot and Klondike were named for the farms they came from; Southern Girl may have been specifically (re)named for her role in the expedition. Either way, the cows were walking advertisements for their dairies as well as the Byrd expedition a mutually beneficial arrangement. With the loan of the cows (for a period of two years) came further sponsorship: ten tons of "Larro" feed from the Larrow Milling Company; a Surge Milking Machine; and Jamesway farm equipment. Carefully framed publicity shots ensured that investors could capitalize on their sponsorship, the expedition bestowing on their products not only Byrd's celebrity but also the boast of withstanding the most extreme conditions on Earth. ${ }^{29}$ The AGCC's representative, Elsworth Bunce, was confident of their marketing potential, suggesting that on the animals' return “Jamesway and Larro, Surge Milking Machine Company and the American Guernsey Cattle Club could get together and put on a barn storming tour of the big fairs with a suitable exhibit and probably a team of dogs and a dog sledge. ${ }^{" 30}$ Like huskies and sledges, the dairy cows would (surreally) become a synecdoche for American polar endeavour. 
[Insert Figure one near here. Caption: Figure 1. Publicity shot of Byrd with Deerfoot prior to departure. Source: Wisconsin Historical Society WHS-130655.]

As Deerfoot, Klondike and Southern Girl would themselves be central to such promotional activities, their safe return from Antarctica was paramount. For Byrd, too, their survival was important as proof of prowess: prior to departure, he told the media he intended to show his sceptical friends "that we can bring these cows back and return them to their owners." ${ }^{31}$ In the end, however, only two of the three cows who were obliged to venture south returned.

\section{Guernseys Discover Antarctica: The Cows' Journey}

The cows' long journey began in early October 1933, when Deerfoot and Southern Girl arrived in short succession at the Boston docks to be hoisted on board the Jacob Ruppert. The Guernseys seem to have been latecomers to the expedition, with Byrd negotiating their addition with the secretary of the AGCC the day before Deerfoot's arrival; ${ }^{32}$ this explains why they were sourced from farms on the East Coast, comparatively close to the expedition's departure point. Edgar F. Cox, the ship's carpenter and owner of a 27-head dairy farm, was given responsibility for the animals, and soon began building a cow barn on the starboard side of the forward well deck. ${ }^{33}$ At Norfolk, Virginia, in addition to feed and materials for the barn, a third cow, the pregnant Klondike, was taken aboard: "The Admiral thought it would be a novelty if one of the cows was fairly well along in motherhood, so that a calf might be born on the ice." ${ }^{34}$ Given the length of the journey - it would take over three months to reach their destination at the Bay of Whales in the Ross Ice Shelf the timing of the pregnancy was important.

From Norfolk, with Cox now in sole charge of the cows, the Jacob Ruppert sailed to Valparaiso, Chile, via the Panama Canal, and thence to New Zealand, before turning south to the Ross Ice Shelf 
in East Antarctica - a total of over 15,000 miles. ${ }^{35}$ As the cows gained their "sea-legs," they also began their journey towards stardom, with Paramount cameramen taking the first film footage of them as the vessel headed toward Panama. ${ }^{36}$ They continued to be filmed throughout the voyage and would later feature in their own film, Guernseys Discover Antarctica. ${ }^{37}$ The cows tolerated the tropical weather well, but when the ship left Wellington in New Zealand they were moved from their "ramshackle stall" to a newly constructed barn below deck: "not too soon for within four days the temperature dropped to twenty above zero and we ran into a gale." 38

The weather conditions meant that the ship was behind schedule, putting into peril plans for Klondike's delivery of a calf "on the ice" - or at least inside the polar circle. Unfortunately for the expedition publicity machine, Klondike gave birth to a bull calf nearly 250 miles north of the Antarctic circle. She seemed determined to resist the expedition's expectations in more ways than one, managing to thwart Paramount's attempt to film the event: "[The cameraman] had been up almost all night + day to make movies of the event for the benefit of the Guernsey Association, but during one of his five minute absences, out popped the calf." ${ }^{39}$ Having been impressed by his first sighting of an Antarctic iceberg the night before, Cox named the bull "Iceberg." ${ }^{40}$ News of the birth was quickly telegraphed home to the U.S., where it soon appeared in the New York Times and other media publications.

By mid-January 1934 the Jacob Ruppert had arrived at the Bay of Whales, and the men set about unloading equipment and stores, and surveying, expanding and where possible restoring their former base, "Little America," now buried under many feet of snow. Cox - as a carpenter as well as the expedition dairy-man - was much in demand. On 3 February 1934, in trying conditions, the cows were placed in wooden crates and craned onto the ice - Deerfoot having the honour of first cow on the continent. ${ }^{41}$ According to the February report in the Little America Times, Foremost 
Southern Girl immediately tried to walk back up the gangplank onto the ship. ${ }^{42}$ This Guernsey, at least, seems to have had little desire to discover Antarctica.

Southern Girl's reaction was prescient, as the cows faced a series of trials before they could move into their comparatively comfortable quarters at Little America. The four animals were walked 2.5 miles to a camp and stayed in a makeshift barn made of hay bales, grain bags and a tarpaulin. The following day they were taken to Little America in two trips, with the adults in a crate pulled by a tractor and Iceberg riding in the tractor itself. ${ }^{43}$ While waiting for their barn to be ready, the cows spent three weeks in a tent. With temperatures reaching $-45^{\circ}$ Fahrenheit, their body heat would see them melted into the snow each morning and needing to be pulled up by a "good heave on the halter." 44 The adults all suffered frostbite ${ }^{45}$ - an injury that for Klondike would have significant consequences. Their barn was comfortable by comparison: heavily insulated, with a raised platform for the cows to stand on and a stove to keep temperatures bearable (Figure 2). Byrd's intention to return all four home meant that the cows had to be housed in a tolerable environment. Cox had added incentive to make the space relatively comfortable, as it doubled as his own work and living area; he and another carpenter had their bunks partitioned off in one corner. ${ }^{46}$

[Insert Figure 2 near here. Caption: Figure 2. Cow barn around one week after completion. Source: Edgar Cox, “Dairying in Little America: Part II,” Guernsey Breeders Journal, November 1 (1935): 724.]

For the next year the cows stayed in this barn, with Cox carrying out twice-daily milking, watering, and feeding. Cox "found quite a bit of his time taken up each day in caring for the cows," observed fellow expeditioner Paul Siple, "which were kept groomed and as well-appearing as cows grazing on the most fertile pasture land." 47 They were certainly productive. Although, with no calves other than Iceberg born, the quantity of milk the cows produced dropped off over time, Byrd's men at 
Little America nonetheless had more than they could possibly consume. ${ }^{48}$ In midwinter 1934 the three cows were producing 47 quarts daily - enough to feed the 55 men at the base almost three times over. $^{49}$

By this stage Byrd himself was not at Little America, but rather wintering on his own at an outpost he called Advanced Base, 120 miles into the interior of the iceshelf towards the Pole. Byrd justified his decision to abandon the men he was leading and spend five months by himself in scientific and practical terms, but this "first," like the cows" inclusion in the expedition, can just as easily be read as publicity-driven - another attempt to create the "spectacular objective" that the leader knew his second expedition lacked. ${ }^{50}$ Cows could not venture to Advance Base - and would also have detracted from Byrd's contrived isolation - but "fifteen Gallons of Guernsey milk frozen in cans" were taken in the supply plane. ${ }^{51}$ Byrd's bestselling account of his experience, Alone (1938), famously details his descent into despair and near-madness largely due, it transpired, to carbon monoxide poisoning from his stove. Eventually he was evacuated back to Little America where, according to the Guernsey Breeders Journal, he indulged in large amounts of fresh milk. "The Milk Really Pulled Me Out of My Tailspin" states the explorer in a headline used in the journal, which goes on to report: "Returning to Little America ... Admiral Byrd found the one vestige of civilization on which he depends so much, fresh milk ... No member of the Expedition drank as much milk as did Admiral Byrd. Two quarts a day and more ..." ${ }^{.52}$

While the cows continued to address the expedition's "milk problem" more than adequately for a good part of the year, their publicity value gradually subsided. When the next news occurred, it suggested that the cows' experience was not as uniformly positive as reports insisted. Despite the attempts to make the Guernseys' living space tolerable, Klondike never fully recovered from her early frostbite, which in the latter part of the year spread into a "ghastly sore"; Cox also suspected she consumed a piece of metal sometime in the winter. ${ }^{53}$ While he and the expedition doctor Louis 
Potaka treated her regularly, there was little improvement: "it looks bad for her", wrote Cox in a rare emotional outburst in his diary in early December 1934, “... I hate like the devil to do away with her but I suppose in the end she will have to go." ${ }^{54}$ Potaka shot Klondike through the head with a rifle just after midnight on 16 December, while Cox blocked Southern Girl's ears (Deerfoot and Iceberg had been taken to the hay cache some distance away). The carpenter was visibly tearful. ${ }^{55}$ With help from three other men, he buried Klondike's body in the snow in "an abandoned part of the hay cache. ${ }^{56}$ Not long after her death, the men took advantage of Deerfoot and Iceberg's removal and tried to mate them. Presumably this was another attempt at a first - a cow conceived in Antarctica - but again the Guernseys had other plans: Iceberg "didn't like the idea." ${ }^{\text {"T }}$ The expedition narrative terms Iceberg a "complete disappointment" in his inability to perform his “expedition duties," speculating that this was "either on account of his extreme youth or a congenital coolness, not surprising in one so named." ${ }^{58}$ The tongue-in-cheek tone is typical of the way the cows are described in the narrative, but the series of events - Klondike's shooting, her burial in the snow, the attempted mating in the hay cache - all in the early hours of a Sunday morning seems far bleaker as reported in Cox's diary, in his characteristically unvarnished style.

The three remaining cows maintained their health for two more months, and when the Jacob Ruppert moored next to the ice in early February 1935, they were "jerked up one by one in a crate into which they were peremptorily jimmied by the impatient shore crew [and] deposited into the forward well deck." Their expressions, Byrd noted, did not divert from the "melancholy with which they had contemplated the whole expedition." 59 Deerfoot, Southern Girl and Iceberg returned in good health, but they had spent a year enclosed in a cold barn, "with no exercise for twelve months - tied up all day.. ${ }^{60}$ Although expeditioners gave positive reports - Bob Young, an ex-farmer, considered them "quite contented and happy" 61 - melancholy would have been an understandable response to their Antarctic sojourn. 
The Guernseys' experience, however, had yet to reach its highpoint. When the Jacob Ruppert docked in Virginia in May 1935, photographers rushed to get cow pictures. The record-breaking Iceberg - now a 1,100-pound bull - was particularly feted, invited to luncheons and farm shows as the guest of honour. He and Southern Girl were quickly taken to Washington D.C., where they met dignitaries including the secretary of Agriculture Henry A. Wallace - a scene captured by three newsreels and fifteen cameras and "wirephotoed over the country." 62 The cows went on to New York City, and by mid-May were being presented to the annual luncheon meeting of the AGCC, held at the Hotel Commodore in New York. ${ }^{63}$ They ate "hay cocktails" and listened to speeches although Iceberg "grunted vociferously" throughout. ${ }^{64}$ The events made headlines in the New York Times. ${ }^{65}$ Meanwhile, Deerfoot, who had travelled north on the Jacob Ruppert, was taken to Boston Common, where she became "the first cow to graze ... in probably 100 years." She was milked for the ubiquitous photographers and presented with the key to the city. Deerfoot went on to the Statler Hotel, where she met the Governor of Massachusetts and tried on his silk top hat - the photograph becoming "front page news."

Capitalizing on this press, the AGCC organized the anticipated barnstorming tour: the cows travelled in a specially marked Dodge truck to a series of fairs and live stock shows across the Eastern states of America, with Cox relating his experiences to the fairgoers. Over the next few years he would speak and show film footage to numerous school and community groups across the country (Figure 3). Meanwhile, the cows returned to their respective farms, where they retained local fame for some time to come. ${ }^{67}$ As one history of the Cattle Club notes, “there hasn't been a dairy cattle promotion scheme that got that much news coverage and publicity before or since."

[Insert Figure 3 near here. Caption: Figure 3. Slide from Cox's lecture tour. Byrd Polar and Climate Research Centre, Cox Box 1, Folder 14.] 
For Byrd, the AGCC, and arguably the surviving cows,${ }^{69}$ the unusual experiment had been a success. For the AGCC, it brought publicity from both the reflected glory of the expedition's achievements and the novelty of cows having survived a year at the "South Pole." For Byrd, it went some way to providing the kind of popular spectacle he had worried his expedition was lacking. At another level, it reinforced the image he was cultivating of Little America as a frontier settlement, the kind of "town" which might boast its own "dairy." There were, however, other benefits that Byrd derived from taking the Guernseys. These revolved around the particular associations of milk in the interwar period - associations that made it a particularly good "brand fit" for Byrd's purposes, and that shored up the U.S. nationalism attached to the expedition.

\section{Cows, Milk and Meaning}

When the AGCC announced in a press release in late 1933 that Byrd's cows were "expected to take care of the milk problem for the expedition," a double meaning would have been evident to many of their audience. On the one hand, the immediate "problem" was simply the absence of access to this beverage on board ship and in Antarctica. The assumption that milk was a required food for healthy adults was a very recent one. Only a few decades earlier milk had been considered the province of children and invalids, but by the 1930s not only was it well accepted in the United States as a dietary staple, it was promoted as an ideal food. On the other hand, "the milk problem" was a reference to milk's chequered history: the phrase (sometimes "the milk question") had been prominently used to summarize a prominent public health issue, particularly in New York, Boston and other large cities, in the early twentieth century: how to ensure access to fresh and disease-free milk. Public campaigns, alongside scientific advancements such as pasteurization, meant that by the time Byrd's second expedition left, this “problem" for the U.S. public was largely over. Milk consumption had "increased markedly," doubling in New York City between 1890 and $1930 .{ }^{70}$ Milk was now so central to the national diet that its absence could well be considered a "problem." 
Milk, then, had specific social and national connotations in the 1930s. Its associations were multiple: with "mothers, nurturance, and wholesome 'natural' food"; with "purity and abundance"; ${ }^{71}$ and with a supposed bucolic tradition that stretched back to the early years of America's European settlement. ${ }^{72}$ The promotion to American households of a liquid strongly associated with purity and whiteness had obvious racial implications. Milk consumption became "part of standard Americanization techniques," with immigrant and African American mothers encouraged to adopt it. In Nature's Perfect Food: How Milk Became America's Drink, E. Melanie De Puis argues that "The establishment of white racial hegemony and the celebration and purification of a white substance digested predominantly by this group [was] more than accidental." ${ }^{, 73}$ This association with whiteness resonated with Antarctica's aesthetic stereotype. Like milk's, Antarctica's whiteness signified more than a chromatic quality; it is and was "often imbued with cultural connotations of purity, fragility, and even superiority." ${ }^{\prime 74}$ Although the history of Antarctic exploration is more racially diverse than "Heroic Era" accounts might suggest, all of the famous exploration narratives of the period focus on white actors. ${ }^{75}$ The first known African American to reach Antarctica was George W. Gibbs, Jr., who was a member of Byrd's Third Antarctic Expedition (1939-41).

Milk was (and is) also highly gendered. While the production of milk was so closely tied to motherhood, its consumption had, by the 1930s, become associated with vigorous American masculinity, partly through the campaigns of temperance advocates who promoted it (particularly the malted variety) as an alternative to alcohol. ${ }^{76}$ "The Americans are great milk drinkers," claimed a 1935 article in the British Sunday Post, "They average a quart a day. The men will go into a bar and order a glass of milk without a blush, drink it, and walk out again with their heads held high."77 Milk bars in Britain were thus "sanctioned by the example of America and all the New World's vigour, drive and wealth." 78 Byrd, drinking two quarts a day after his trial at Advanced Base to pull 
himself out of his "tail spin," was thus imbibing a liquid associated with American national character, manly wholesomeness, health and energy.

Dairy-cows, who produced this vitalizing substance, had the opposite set of associations: passivity and docility. It was partly the stereotypically feminine qualities attached to the cows, in contrast to the masculinized space of Antarctica, that made the idea of cow-explorers in the frozen south so incongruous and hence newsworthy and which led to their frequent framing as comic creatures in Byrd's narrative and in the media. At the time of Byrd's expedition, Antarctica was assumed to be a place of entirely masculine endeavour. There is no record of any female human having set foot there prior to 1935, when Carolyn Mikkelsen, the wife of a Norwegian whaling captain, came ashore briefly in East Antarctica - and even this became publicly known only years later. ${ }^{79}$ Deerfoot, Klondike and Southern Girl, steadily producing the liquid that would maintain the men's vigour but taking no active part in the expedition - rarely even venturing outside - reinforced the gendered construction of exploration as an activity and Antarctica as a place. It is no coincidence that when the first women did winter in Antarctica, in the U.S. Ronne expedition in the late 1940s, they were likened to Byrd's Guernseys. In her memoir My Antarctic Honeymoon, Jennie Darlington reports one man's reaction to her inclusion (along with another woman) in the expedition: “"The admiral took along Guernseys,' he said calmly. "One had a calf - the first domestic animal born below the Antarctic Circle [sic]. We might do better!"80

The cultural meanings of cows, in conjunction with milk itself, are important to understanding the symbolic work of Byrd's Guernseys. Even accepting the view at the time that milk was a healthy and necessary part of the adult diet, cows on site were not the only - and certainly not the simplest way in which this beverage could be included in the expeditioners' rations. Powdered milk, patented in the U.S. in 1872, holds its nutritional value for up to four years - far longer than Byrd required. ${ }^{81}$ While there had been scandals over its adulteration in the late nineteenth century, 
powdered milk had been used successfully in a number of polar expeditions prior to Byrd's. British expedition leaders Robert F. Scott and Ernest Shackleton, Australian Douglas Mawson, Norwegian Roald Amundsen and American North Polar explorer Robert Peary had all used powdered and/or malted milk. Byrd was certainly aware of powdered and malted options, both of which he took with him to Advance Base alongside the frozen milk from the expedition cows. Indeed, one of his key sponsors was his “old friend” William Horlick, the malted-milk manufacturer who provided a "substantial cash donation" with which the leader was able to buy a long-range plane, named after its benefactor. ${ }^{82}$ As a result, malted milk is writ large over the Antarctic continent in the form of the Horlick Mountains in Marie Byrd Land - Byrd's payment-in-kind for the sponsorship.

Unsurprisingly, crates of Horlicks also accompanied the expedition and featured in advertisements for the product, endorsed by statements by Byrd recounting his own daily consumption of the product and its benefits to his men and dogs (Figure 4). ${ }^{83}$ While its powdered form detracted from the idea of freshness so important to milk's marketing, malted milk had other useful associations: with the added bulk of wheat flour and malted barley, it was considered a hearty meal drink that had a particular appeal to men. ${ }^{84}$

[Insert Fig. 4 near here. Caption: Figure 4. Promotional image for Horlick's Malted Milk.

Photographer: Benjamin Morse. Source: Wisconsin Historical Society, WHS-23703.]

In all of its varieties, then, milk brought associations that were useful to Byrd as the leader of an Antarctic expedition. Milk stood for whiteness, health, energy and wholesome masculinity. More importantly, as “America's drink” it reinforced the expedition's national character and purpose. But fresh milk was clearly important to Byrd. At the basic level of expeditioner health, he could have solved the so-called "milk problem" in ways far less burdensome than by accommodating a group of Guernseys on his ship and his base. Byrd's insistence on fresh milk seems underdetermined by the supposed health issues, and points back to the settler colonial imaginary that he drew on in 
undertaking and marketing his Antarctic expeditions. Milking in Antarctica - as opposed to bringing milk in various forms to Antarctica - signified fresh produce and farming, and hence a sense that the expedition was not just sojourning but somehow settling in the far south. Taking cows to the Ross Ice Shelf to produce fresh milk helped imaginatively to turn the men from explorers into settlers, and Little America from a base into a colony.

\section{Animal Histories, Imperial Histories, Antarctic Histories}

While the significance of the nonhuman environment in imperial history been recognized for several decades, the subfield of "animals and imperialism" is still developing rapidly. Outlining "recent historiographical trends" in this area, Aaron Skabelund divides approaches into three categories: studies that attend closely to the relationships between animals and people, "elevat[ing] animals as more direct partners in a relationship with humans, rather than as minor bit players"; those that focus on the symbolic dimension of human-animal interactions, "the figurative as well as the practical deployment of animals"; and those that deal with animal agency, taking animals "more seriously as historical subjects," including the fraught task of "giving voice to animals." He concludes by pointing to some directions for future studies of animals and imperialism, such as the need for "more histories of all kinds and places ... many other geographic contexts and aspects of the relationship between animals and imperialism remain to be explored." ${ }^{85}$

Our account of the Antarctic journey of Deerfoot, Klondike and Southern Girl - and, later, Iceberg - can readily be placed in Skabelund's first two categories, and to a certain extent in the third. Brief instances of the cows' foiling of human plans and even their voices are certainly evident in the records of their journey: Klondike's delivery of her calf out of the camera's view; Southern Girl's attempt to reboard the ship; Iceberg's refusal to perform his expedition "duties" and his vociferous grunting during formal speeches. If these animals were agents of empire, they were, it seems, 
remarkably reluctant ones. Certainly their agency operated very differently from that of cattle and other animals in more temperate parts of the world (including subantarctic islands), where the material impact of introduced species on the local environmental could be quite marked.

Our account of Byrd's cows better answers Skabelund's final call for more histories of animals and imperialism "of all kinds and places." As the only continent with no indigenous humans, or any land-based species above the size of a midge, Antarctica offers the opportunity to consider both human-animal relations and colonial histories from a rarely glimpsed perspective. Following the journey of Deerfoot, Klondike and Southern Girl helps us to reframe understandings of the U.S.'s relationship with Antarctica, and Antarctic exploration and occupation more generally. Far more than the solution to the supposed "milk problem," the cows carried with them a rich symbolism tied to nation, race, gender and territory. They weren't just cows in Antarctica, they were American cows, and their presence helped to turn a base into a ranch or a farm, a symbolic version of the kind of frontier settlement that early American colonists used to establish their own nation.

\section{Acknowledgements}

This work was supported by the Australian Research Council (project FT120100402) and by a McColl Fellowship to the American Geographical Society Library in Milwaukee, Wisconsin (2015). We are grateful to Alessandro Antonello, Helen Tiffin and the anonymous reviewers for their useful feedback on earlier forms of this article, and to Laura Kissel, polar curator at the Byrd Polar and Climate Research Center, for her generous help with sourcing archival documents.

1 “S.S. Jacob Ruppert is Floating Zoo," Little America Times, May 31, 1935, B4. The popularity of Antarctic animals at the time is indicated, among other things, by the success of Richard and 
Florence Atwater's children's novel Mr. Popper's Penguins (1938), originally inspired by Byrd's first expedition. In the novel, "Admiral Drake" makes a present of an Antarctic penguin to the eponymous tradesman and polar enthusiast, who eventually joins Drake's expedition to establish penguins in the Arctic.

2 The only publication in which the cows take centre stage is Eileen Spinelli and Bill Slavin's picture book for children, Something to Tell the Grandcows (Grand Rapids, MI: Wm. B. Eerdmans, 2004).

${ }^{3}$ Admiral Byrd takes Larro to the South Pole (Larrow Milling Company: Detroit, Michigan. 1934),

2. Cornell University, SF99 L33.

${ }^{4}$ See e.g. Hilda Kean, “The Animal Turn,” Dadalus 136.4 (Fall 2007): 118-22.

${ }^{5}$ Cattle were on Deception Island from the early twentieth century, but for meat rather than dairying. See Robert Headland, "History of Exotic Terrestrial Animals in the Antarctic Regions," Polar Record 48 (2012): 134. As Headland notes, there were also cattle populations on various subantarctic islands during the nineteenth and twentieth centuries.

${ }^{6}$ American Guernsey Cattle Club, “Polar Guernseys Withstand First Test” (Press Release), n. pag. November 4, 1933. State Historical Society of Wisconsin, Box 12, Folder 8, Whitewater Mss AW Publicity Files, So. Pole Expedition, 1933-1934.

${ }^{7}$ Admiral Byrd takes Larro, 2

${ }^{8}$ For convenience, we use the term "cows" here and occasionally below to include Iceberg the bull, given that there is (tellingly) no plural non-gender-specific term for these animals except the collective noun "cattle," which seems inappropriately de-individualizing for our purposes here.

${ }^{9}$ Klaus J. Dodds, “Sovereignty Watch: Claimant States, Resources, and Territory in Contemporary Antarctica." Polar Record 47 (2011): 234.

${ }^{10}$ The Treaty does not extinguish the existing territorial claims, although it does stipulate that these cannot be enlarged, or new claims made, while it is in force. 
${ }^{11}$ Klaus Dodds, "Post-Colonial Antarctica: An Emerging Engagement." Polar Record 42 (2006): $59-70,61$.

${ }^{12}$ See Christy Collis, “Mawson's Hut: Emptying Post-Colonial Antarctica,” Journal of Australian Studies 63 (1999): 22-29; and Christy Collis and Quentin Stevens, "Cold Colonies: Antarctic Spatialities at Mawson and McMurdo Stations," Cultural Geographies 14 (2007): 234-54. 13 Adrian Howkins, “Appropriating Space: Antarctic Imperialism and the Mentality of Settler Colonialism," in Making Settler Colonial Space: Perspectives on Race, Place and Identity, ed. Tracey Banivanua Mar and Penelope Edmonds (Houndmills, Basingstoke, Hampshire: Palgrave Macmillan, 2010), 48.

${ }^{14}$ Although the 1959 Antarctic Treaty effectively suspended all existing claims, it did not put an end to U.S. interest in the region: along with the Soviet Union, the U.S. refused to recognize other claims and reserved the right to make its own in the future. The establishment in 1956-7 and ongoing maintenance of a U.S. station at the South Pole - where the territorial claims meet - was and is a pointed and strategic occupation of the most politically symbolic place on the continent. See Elizabeth Leane, South Pole: Nature and Culture (London: Reaktion, 2016), ch. 8.

${ }^{15}$ Lisle A. Rose, Explorer: The Life of Richard Byrd (Columbia and London: University of Missouri Press, 2008), 313-4; 398; 497 n.2.

${ }^{16}$ Little America was in the Ross Dependency, claimed about ten years earlier by New Zealand (both Australia's and New Zealand's claims were delegated to them by the United Kingdom); but it was close to the unclaimed sector of the continent, which Byrd had previously surveyed by air and named after his wife Marie.

${ }^{17}$ Byrd could trace his lineage back to the "First Families of Virginia" - prominent early settlers of the fledgling colony. See Rose, Explorer, 8.

${ }^{18}$ See Elena Glasberg, "Who Goes There? Science, Fiction and Belonging in Antarctica?" Journal of Historical Geography 34 (2008): 646; David Day, Antarctica: A Biography (North Sydney:

Knopf, 2012), ch. 13. 
${ }^{19}$ Stephen J. Pyne. The Ice: A Journey to Antarctica (New York: Ballantine, 1988), 101-2.

${ }^{20}$ Richard Evelyn Byrd, Discovery: The Story of the Second Byrd Antarctic Expedition (Freeport, NY: Books for Library Press, 1972 [1935)]), facing 121.

${ }^{21}$ See Virginia DeJohn Anderson. Creatures of Empire: How Domestic Animals Transformed Early America (Oxford: Oxford UP, 2004), ch 3; and John Ryan Fischer, Cattle Colonialism: An Environmental History of the Conquest of California and Hawai ' $i$ (Chapel Hill: University of North Carolina Press, 2015).

${ }^{22}$ This makes sense too of the attempt to mate Deerfoot and Iceberg, late in the expedition when there was no particular need for more milk: a farm animal born (or at least conceived) in Antarctica would reinforce this sense of settling the continent. Certainly a similar logic was later applied to humans, with Argentina and Chile sending women to give birth in Antarctica to reinforce their territorial claims.

${ }^{23}$ Peder Roberts and Dolly Jørgensen, “Animals as Instruments of Norwegian Imperial Authority in the Interwar Arctic," Journal for the History of Environment and Society 1 (2016): 66, 70-71. ${ }^{24}$ The validity of Byrd's north polar overflight has since been called into question. For an assessment of the debate, see Rose, Explorer, 123-43.

${ }^{25}$ Byrd, Discovery, 6-7.

${ }^{26}$ Byrd, Discovery, 11-12. The Australasian Antarctic Expedition (1911-14) had inaugurated the use of radio but due to weather and technical difficulties was unable to maintain regular contact. ${ }^{27}$ Robert N. Matuozzi, "Richard Byrd, Polar Exploration, and the Media," The Virginia Magazine of History and Biography 110.2 (2002): 209-36.

${ }^{28}$ American Guernsey Cattle Club, "Polar Guernseys."

${ }^{29}$ For an analysis of media, sponsorship and Byrd's cows, see Hanne Nielsen, "Hoofprints in Antarctica: Byrd, Media, and the Golden Guernseys," The Polar Journal 6.2 (2016): 342-57.

${ }^{30}$ Elsworth Bunce, Letter to C.L. Burlingham, November 10, 1933, State Historical Society of Wisconsin, Box 12, Folder 8, Whitewater Mss AW Publicity Files, So. Pole Expedition, 1933-1934. 
${ }^{31}$ Admiral Byrd takes Larro, 3.

32 Edgar Cox, "Dairying in Little America," Guernsey Breeders' Journal, October 1, 1935, 500.

${ }^{33}$ Admiral Byrd takes Larro, 6; Edgar Cox. Diary (4 Log Books). Box 1, Folder 3, Edgar F. Cox Papers, BPRCAP.2010.1, Byrd Polar Research Center Archival Program, The Ohio State University. 11 Oct. 1933.

${ }^{34}$ Cox, “Dairying," 500.

${ }^{35}$ Byrd (Discovery, 69) gives the journey length as 13,323 nautical miles.

${ }^{36}$ Leroy Clark, Telegraph Message to Elsworth Bunce, October 28, 1933, State Historical Society of Wisconsin, Box 12, Folder 8, Whitewater Mss AW Publicity Files, So. Pole Expedition, 19331934; Cox, "Dairying," 501.

${ }^{37}$ See e.g. The News-Herald (Franklin, PA), May 4, 1936, 8.

${ }^{38}$ Byrd, Discovery, 24. Cox, "Dairying," 501.

${ }^{39}$ Stuart D. Paine, Footsteps on the Ice: The Antarctic Diaries of Stuart D. Paine, Second Byrd Expedition, ed. M.L. Paine (Columbia: U of Missouri P, 2007), 46.

${ }^{40}$ Cox, Diary, 18 and 19 Dec. 1933.

${ }^{41}$ Cox, "Dairying," 514. Some might quibble that the Ross Ice Shelf, with no bedrock beneath it, is not part of the Antarctic "continent." However, as most of Antarctica is covered by a thick ice sheet, and a good deal of the bedrock is below sea level, the point is somewhat moot. The continent is usually assumed to include its ice sheets and shelves.

42 “Byrd's Cows and Calf Taken to Base," Little America Times, February 28, 1934, B2.

${ }^{43}$ Cox, "Dairying" 517; Edgar Cox "Dairying in Little America: Part II," Guernsey Breeders Journal, November 1, 1935, 724.

44 "Hot Spots on the Antarctic," Guernsey Breeders Journal July 1, 1935, 17.

${ }^{45}$ Cox, "Dairying: (Part II)," 725.

${ }^{46}$ Byrd, Discovery, 189. 
${ }^{47}$ Paul Siple, Scout to Explorer: Back with Byrd in the Antarctic (New York: G.P. Putnam's Sons, 1936), 103.

${ }^{48}$ Dairy cows do not continue to produce milk indefinitely, but only for a certain period after the birth of a calf, which can depend on the breed and specific circumstances.

49 “Intense Cold Does Not Bother the Cows who Give about 47 Quarts of Milk a Day." Little America Times, July 26, 1934, B8.

${ }^{50}$ Byrd, Discovery, 6. See also Matuozzi, "Richard Byrd," 230.

51 "Hot Spots on the Antarctic," Guernsey Breeders Journal, July 1, 1935, 17.

52 “The Milk Really Pulled Me Out of My Tailspin,” Guernsey Breeders Journal, June 15, 1935, 628.

${ }^{53}$ Byrd, Discovery, p. 334. Cox, “Dairying: (Part II)," 767.

${ }^{54}$ Cox, Diary, December 2, 1934.

${ }^{55}$ Byrd, Discovery, 349.

${ }^{56}$ Cox, Diary, December 15, 1934.

${ }^{57}$ Cox, Diary, December 15, 1934.

${ }^{58}$ Byrd, Discovery, 183.

${ }^{59}$ Byrd, Discovery, 381.

${ }^{60}$ Bob Young, With Admiral Byrd's Second Antarctic Expedition: H. R. (Bob) Young's Narrative Account of His Experiences Down South and Return to Civilization, ed. Bruce Young, Ohio State University Knowledge Bank, 2008, http://kb.osu.edu/dspace/handle/1811/35732, December 15, 1934.

${ }^{61}$ Young, With Admiral Byrd's Second Antarctic Expedition, May 1, 1934.

62 “America Welcomes the Byrd Guernseys,” Guernsey Breeders' Journal, June 1, 1935, 560;

“Byrd's Bull Spurns First Offer of Grass,” Little America Times, May 31, 1935, B5.

63 “Byrd Cattle Eat Lunch at Hotel," Little America Times, May 31, 1935, B5.

64 "Byrd Cattle Eat Lunch." 
65 "America Welcomes the Byrd Guernseys," 560.

66 “America Welcomes the Byrd Guernseys," 560.

${ }^{67}$ In a note to the "Antarctic Circle" website, Joe Merriman, who worked at Deerfoot Farm as a boy in 1942, notes that "Pride of place in the first cow shed belonged to an old Guernsey cow who had spent 1930 [sic] with Admiral Byrd in Little America." See "Some Cows that Headed South in 1933," March 19, 2000 update, http://www.antarctic-circle.org/E07.htm.

68 Tom Shultz, A 1940s Monadnock Childhood (Charleston and London: History Press, 2011), 32.

${ }^{69}$ Iceberg, for one, benefitted from his Antarctic birth and later fame; the usual fate of a bobby calf in the dairy industry is separation from his mother and then slaughter at an early age.

${ }^{70}$ Daniel Block, "Milk," The Oxford Encyclopedia of Food and Drink in America, ed. Andrew F. Smith (New York: Oxford UP, 2013), 582.

${ }^{71}$ Deborah Valenze, Milk: A Local and Global History (New Haven and London: Yale UP, 2011), $260,4$.

${ }^{72}$ As E. Melanie Du Puis and others make clear, the widespread adoption of milk as a drink actually had its origins in urban settings in the nineteenth-century. E. Melanie Du Puis, Nature's Perfect Food: How Milk Became America's Drink (New York and London: New York UP, 2002), 4-5.

${ }^{73}$ Du Puis, Nature's Perfect Food, 14.

${ }^{74}$ Lize-Marié van der Watt and Sandra Swart, “The Whiteness of Antarctica: Race and South Africa's Antarctic History," in Antarctica and the Humanities, ed. Peder Roberts, Lize-Marié van der Watt and Adrian Howkins (London: Palgrave Macmillan, 2016), 126.

${ }^{75}$ Early sealing expeditions often had racially heterogeneous crews, including indigenous peoples of various regions; European expeditions would sometimes include non-white people for specialist tasks, such as the Sami dog-drivers on the British Antarctic Expedition; and the Japanese Antarctic Expedition (1910-12) was an exception to European dominance of exploration of the region.

${ }^{76}$ Patrician M. Kelly, "Milkshakes, Malts and Floats," in The Oxford Encyclopedia of Food and Drink in America, ed. Andrew F. Smith (New York: Oxford UP, 2013), 590. 
${ }^{77}$ Qtd in Francis McKee, "The Popularisation of Milk as a Beverage during the 1930s," in Nutrition in Britain Science, Scientists and Politics in the Twentieth Century. ed. David F. Smith (London and New York: Routledge, 1997), 137.

${ }^{78}$ McKee, "Popularisation,” 137.

${ }^{79}$ Moreover, like many Antarctic “firsts," Mikkelsen's landing has since been questioned: she may, it seems, have stood on an island, making Ingrid Chistensen, the wife of Mikkelsen's employer, the first woman to stand on the continent in 1937. See Jesse Blackadder, "Afterword," in Chasing the Light: A Novel of Antarctica (Sydney: Fourth Estate-HarperCollins, 2013), 421-422.

${ }^{80}$ Jennie Darlington, as told to Jane McIlvaine, My Antarctic Honeymoon: A Year at the Bottom of the World (London: Frederick Muller, 1957), 68. This passage foreshadows later events, as Darlington was pregnant when she left Antarctica.

${ }^{81}$ Esther Della Reese, "Milk: Powdered," in The Oxford Encyclopedia of Food and Drink in America, ed. Andrew F. Smith (New York: Oxford UP, 2013), 588.

${ }^{82}$ Byrd, Discovery, 16.

${ }^{83}$ Richard E. Byrd, and Thomas C. Poulter, The Romance of Antarctic Adventure (New York: J.W. Clement Co, 1935). The unpaginated booklet features a two-page Horlicks advertisement. ${ }^{84}$ Kelly, "Milkshakes, Malts, and Floats," 590.

${ }^{85}$ Aaron Skabelund, “Animals and Imperialism: Recent Historiographical Trends,” History Compass 11/10 (2013), 802, 803, 804, 805. 